Archive for

Organic Chemistry

Arkivoc 2020, part vi, 73-83

\title{
DEAE-cellulose-catalyzed synthesis of 5-hydroxy-isoxazolidines and their synthetic uses towards nucleoside analogues
}

\author{
Karzan K. Aljaf, ${ }^{a, b}$ Ahmed Anwar Amin, ${ }^{a}$ Faiq H. S. Hussain, ${ }^{b}$ and Paolo Quadrelli ${ }^{* c}$ \\ ${ }^{a}$ Salahaddin University, Chemistry Department, College of Science, 44001 - Erbil, Kurdistan, Iraq \\ ${ }^{b}$ Medical Analysis Department, Faculty of Science, Tishk Intern. University, 44001 - Erbil, Kurdistan, Iraq \\ ${ }^{c}$ University of Pavia, Department of Chemistry, Viale Taramelli 12, 27100 - Pavia, Italy \\ Email: paolo.quadrelli@unipv.it
}

Received 01-24-2020

Accepted 03-30-2020

Published on line 04-03-2020

\section{Abstract}

5-Hydroxy-isoxazolidinic heterocycles can be easily prepared from hydroxamic acids and suitable $\alpha, \beta$ unsaturated aldehydes or ketones in good yields from solid state synthesis, selectively promoted by DEAE-C. The synthesized products were efficiently derivatized with representative heterobases for the preparation of nucleoside analogues suitable for biological evaluation and SAR analysis.



Keywords: DEAE-Cellulose, isoxazolidines, nucleoside analogues, heterobases, hydroxamic acids 


\section{Introduction}

5-Hydroxy-isoxazolidines are heterocyclic compounds with an hemi-acetal structure, closely related to the isoxazolidine family and quite interesting from the synthetic point of view. The presence of the hydroxyl group in the position 5 of the heterocyclic ring makes this scaffold suitable for derivatization and functionalization of different types. ${ }^{1}$ Their synthesis offers, even recently, new approaches such as the spiro-pyrrolidine 3catalyzed tandem aza-1,4-addition/hemi-acetalization reaction (Scheme 1) between substituted hydroxylamines 1 and $\alpha, \beta$-unsaturated aldehydes $\mathbf{2}$, developed with excellent enantioselectivity and several substrates were used and it was found that the reactions proceeded with higher ee for product 4 compared with the literature data. ${ }^{2}$ The obtained chiral skeleton 4 is the key structure for the synthesis of antiviral compounds where the hydroxyl group in 5 is suitably replaced with heterobases. ${ }^{3}$

Furthermore, the presence of $\mathrm{O}_{2}$ and copper salt additives promotes the [3+2]-annulation reactions of $\mathrm{N}-$ hydroxyaniline 6, bearing an allene moiety, with nitrosobenzenes 5 to form isoxazolidin-5-ol derivatives $7{ }^{4}$ These scaffolds were then oxidized to get highly functionalized indoles.

The synthesis of $\mathrm{N}$-aroyl-5-hydroxy-isoxazolidines of type $\mathbf{1 0}$ (Scheme 1 ) can also be performed in a twostep protocol based on the ene reaction of nitrosocarbonyl intermediates $\mathbf{8}$ with silyl-protected allylic alcohols 9 via an anti-Markovnikov pathway followed by fluoride-mediated deprotection/cyclization process leading quantitatively to the heterocycles 10 , in a one-pot procedure. ${ }^{5}$

a)<smiles>[R]NO</smiles>
1

b)<smiles>[R]c1ccc(N=O)cc1</smiles>
5<smiles>[R]C=CC=O</smiles>

2<smiles>ON([Al])CC=C=CP</smiles>

6

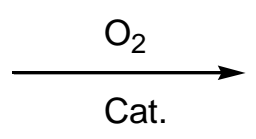

Cat.<smiles>[R]C1CC(O)ON1[R]</smiles>

Ref. 2<smiles>[R]CC1(O)CC(=N[Al])N(c2ccccc2)O1</smiles>

Ref. 3<smiles>[R]C1([R])CC(O)ON1C(=O)[Al]</smiles>

Ref. 4
9<smiles>[R]C=C([P])C(=O)[P]</smiles>

12

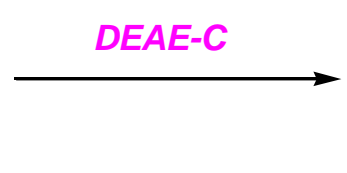

11<smiles>[R]C(=O)NO[OH+]</smiles>
11

Scheme 1. Synthetic approaches to 5-hydroxy-isoxazolidines. 
On pursuing our interests on the generation and synthetic uses of nitrosocarbonyl intermediates of type $\mathbf{8}$, we orientated the attention to the hydroxamic acids, classical precursors of the nitrosocarbonyls, ${ }^{6}$ with the aim to expand the reaction scope taking advantage of the use of an unconventional absorbent based on DEAEcellulose $(\mathrm{DEAE}-\mathrm{C})^{7}$ that is able to promote the cyclization of hydroxamic acids on $\alpha, \beta$-unsaturated aldehydes. ${ }^{8}$ The reaction affords the 5-hydroxy-isoxazolidines in good yields and, more intriguing, in extremely mild way at room temperature and in the solid phase. Here we wish to present scope and limitations of the 5-hydroxyisoxazolidines synthetic protocol as well as the use of the synthesized compounds as scaffolds for the preparation of $\mathrm{N}, \mathrm{O}$-nucleoside analogues by adapting the glycosylation Vorbrüggen methodology. ${ }^{9}$ Furthermore, the tuned synthesis of unsubstituted C3 isoxazolidine scaffolds will offer the possibility to a Structure-Activity Relationship (SAR) evaluation of the prepared analogues as apoptotic agents.

\section{Results and Discussion}

To set-up the experimental conditions we chose the reaction between the benzohydroxamic acid 11a and acrolein 12a as model reaction in the presence of DEAE-C (purchased from Sigma-Aldrich I6505, CAS $n^{\circ}$ 901334-7; Diethylaminoethyl-Sephacel ${ }^{\oplus}$. The reaction was conducted initially with a $1: 1$ molar ratio of 11 a and 12 a at room temperature simply adding the reagents on the solid catalyst DEAE-C (5 g/5 mmol of reagents) and then grinding the mixture in a mortar for a couple of hours (even not continuously; entry 1 of Table 1). The reaction was then left at room temperature for 2 hours before the final work-up that consists of suspending the solid in water and extraction in dichloromethane (DCM) (method MO). The dried organic phase is then evaporated and the reaction mixture is submitted to column chromatography for the isolation and purification of the product. Table 1 summarizes the experiments conducted under different conditions and the yields of the isolated compound of type 13A.

Table 1. Optimization of the reaction conditions in the reaction between benzohydroxamic acid 11a and acrolein $12 \mathrm{a}$ to afford the $\mathrm{N}$-benzoyl-5-hydroxy-isoxazolidine 13A

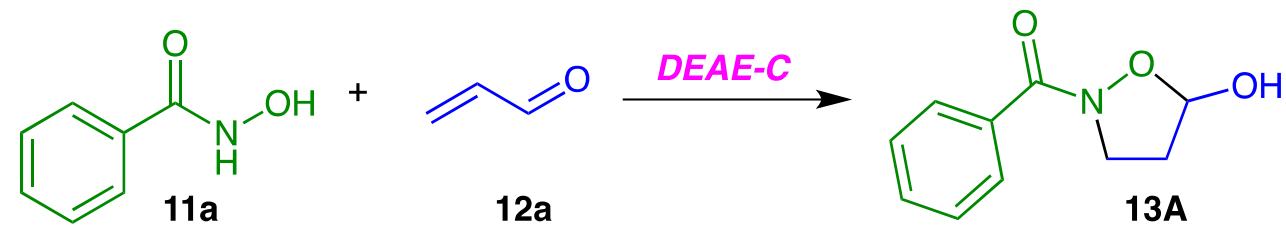

\begin{tabular}{l|lllll}
\hline Entry & $\begin{array}{l}\mathbf{1 1 a} \\
(\mathrm{mmol})\end{array}$ & $\begin{array}{l}\mathbf{1 2 a} \\
(\mathrm{mmol})\end{array}$ & $\begin{array}{l}\text { DEAE-C } \\
(\mathrm{g})\end{array}$ & Method $^{\mathrm{a}}$ & $\begin{array}{l}\mathbf{1 3 A} \\
(\%)\end{array}$ \\
\hline 1 & 5 & 5 & 5 & MO & 66 \\
2 & 5 & 5 & 4 & MO & 62 \\
3 & 5 & 5 & 6 & MO & 63 \\
4 & 5 & 5 & 5 & MW & 59 \\
5 & 5 & 5 & 5 & $1)))$ & 0 \\
\hline
\end{tabular}

a. MO, mixture mixed in a mortar with pestle. MW, microwave. )))), ultrasonic mixing.

The same reaction of entry 1 was repeated with two different amounts of catalyst; in entry 2 the catalyst amount was reduced to $4 \mathrm{~g}$ and in entry 3 it was increased at $6 \mathrm{~g}$. In both cases the 13A yields ranges around 
62-63\% with no improvements with respect to the first experiment. Changes to the ratio of reagents $11 a / 12 a$ from 2:1 to 1:2 were not profitable in terms of yields that were found even lower (ca. $30 \%$ ).

Other methodologies were also investigated with the aim to meet the best experimental conditions affording the desired products at the highest yields possible. Entry 4 reports the result obtained with microwave (MW) heating conducted at $80^{\circ} \mathrm{C}$ for 90 minutes (identical work-up procedure). The yield of 13A was found to be $59 \%$, similar previous results. Finally, a method using ultrasound (entry 5) was also investigated but unsuccessfully. To complete the picture, it is worth noting that no reaction occurs even by refluxing the mixture in solvents (methanol, toluene, DCM) or by adding simply a base such as triethylamine in place of DEAE-C. In conclusion the best and reliable method was to conduct the reaction in the solid state with DEAE-C by grinding/mixing in a mortar with pestle (MO method). Moreover, this methodology affords selectively the 5-hydroxy-substituted isoxazolidines in good yields.

Once fixed the best experimental conditions to carry out the model reaction, we extended the study to some other hydroxamic acids and unsaturated aldehydes to evaluate the scope of the reaction. DEAE-Cmediated reactions were carried out between a variety of hydroxamic acids $\mathbf{1 1 a - d}$ bearing aromatic and aliphatic substituents and some $\alpha, \beta$-unsaturated aldehydes $\mathbf{1 2 a - d}$. The reactions were conducted according the procedure of entry 1 of Table 1 with the aim to prepare the 5-hydroxy-isoxazolidines $13 \mathrm{~A}-\mathbf{H}$, whose structures are shown in Table 2.

Table 2. DEAE-C-mediated reactions between hydroxamic acids $\mathbf{1 1 a - d}$ and $\alpha, \beta$-unsaturated aldehydes $\mathbf{1 2 a - d}$ affording the 5-hydroxy-isoxazolidines 13A-H

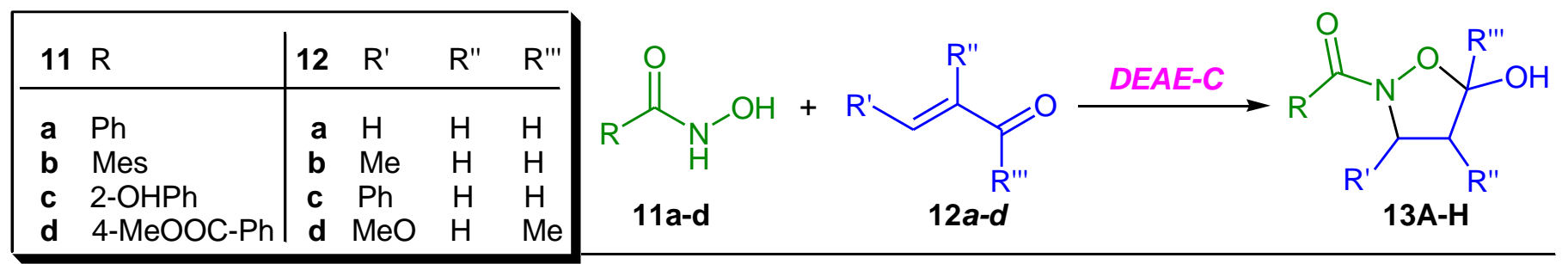<smiles>O=C(c1ccccc1)N1CCC(O)O1</smiles>

$13 A, 66 \%$<smiles>CC1CC(O)ON1C(=O)c1ccccc1</smiles>

13B, $63 \%$

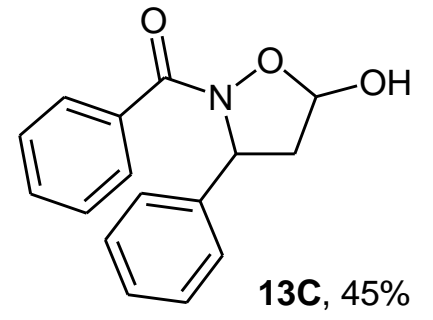

13C, $45 \%$<smiles>Cc1cc(C)c(C(=O)N2OC(O)CC2c2ccccc2)c(C)c1</smiles>

13D, $48 \%$<smiles>O=C(c1ccccc1O)N1OC(O)CC1c1ccccc1</smiles>

$13 E, 49 \%$<smiles>CC1CC(O)ON1C(=O)c1ccccc1O</smiles>

13F, $71 \%$<smiles>CC(=O)c1ccc(C(=O)N2CCC(O)O2)cc1</smiles>

13G, $66 \%$<smiles>[M]C1(O)CC(OC)N(C(=O)c2ccccc2)O1</smiles>

$13 \mathrm{H}, 28 \%$ 
The results clearly indicate scope and limitations of the protocol. In the majority of the reported cases we were able to isolate the desired compounds in good yields as single products. From the reaction mixtures some unreacted hydroxamic acids were also collected. The unsaturated aldehydes produced also some oxidized or polymerized material. Ketones gave worst results and a single case is reported with modest yield. The isoxazolidine derivatives $\mathbf{1 3 A}-\mathbf{H}$ were fully characterized analytically and spectroscopically. The experimental section details their characterization. In particular the structural assignments were based upon the presence in the ${ }^{1} \mathrm{H}$ NMR spectra of the hemiacetalic protons that characterize all the 5-hydroxyisoxazolidine compounds that were found in the range $\delta 5.54-5.69 \mathrm{ppm}$ as expected for these type of protons. Analogously, in the ${ }^{13} \mathrm{C}$ NMR spectra the hemiacetalic carbon atom resonated in the range $\delta$ 97.1-98.4 ppm.

From the mechanistic point of view, Scheme 2 shows the proposed mechanism for the DEAE-C-catalyzed formation of hydroxyl-isoxazolidine 13. Being a positively charged resin, DEAE-C can activate through hydrogen bonding the unsaturated aldehydes or ketones, making them prone to undergo nucleophilic addition by the weak donating nitrogen atom of the hydroxamic acid to afford the Enol intermediate. This intermediate is known to be the direct precursor of the isoxazolidine 13 . The DEAE-C core constitutes somewhat a stabilizing environment of the Enol forms that rapidly cyclize to the desired heterocycles. The proton exchange between the various intermediates restores the DEAE-C nature that is able to restart the cyclization process. The process can somewhat be considered catalytic due to the fact that the amount of ammonium residues on the cellulose skeleton depends on the manufacturers and the loading values are substantially lower than the amount of reagents used for conducting the reactions.
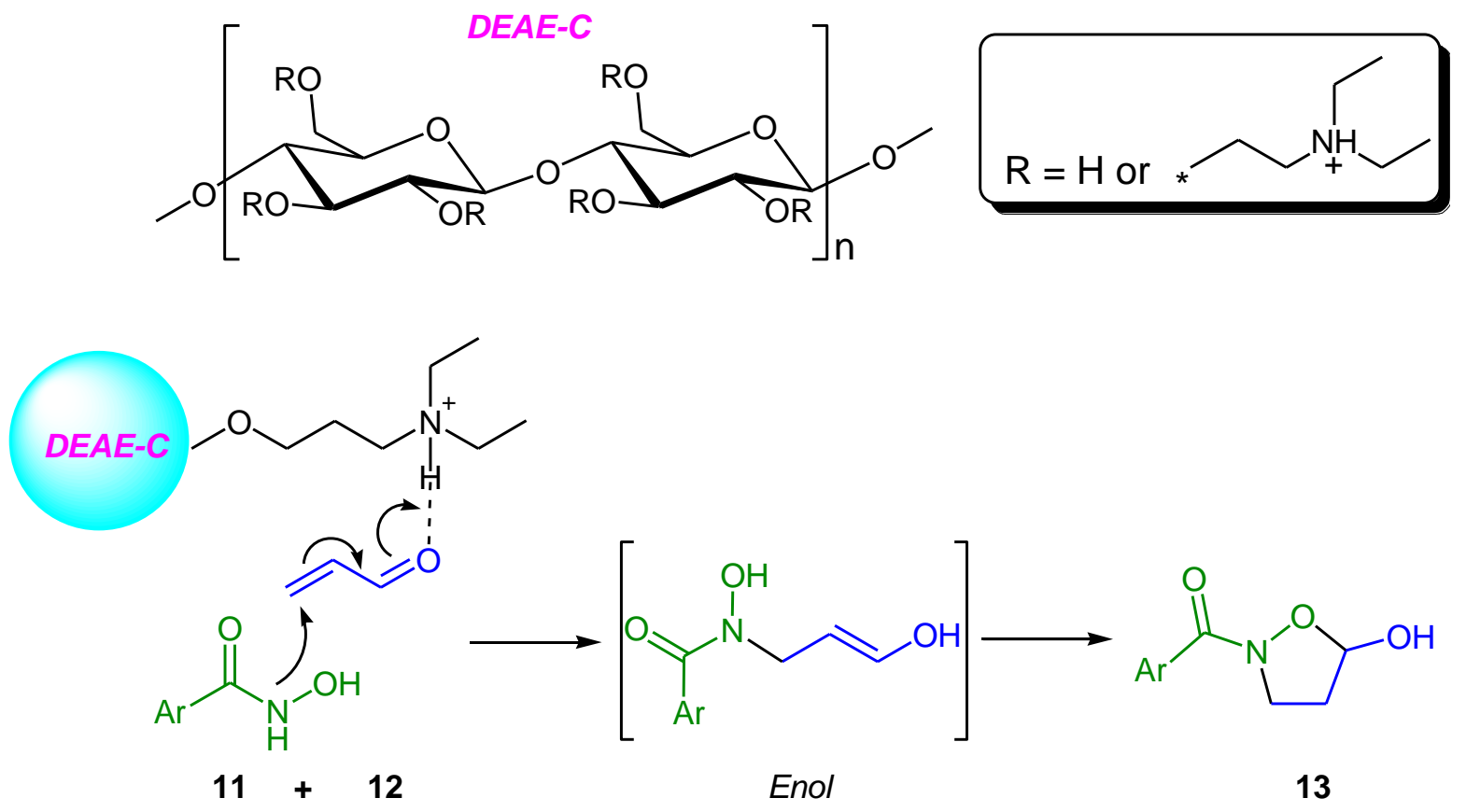

Scheme 2. Proposed mechanism to 5-hydroxy-isoxazolidines.

In previous works ${ }^{3,10-12}$ we prepared and evaluated from their biological activities some nucleoside analogues bearing aromatic or aliphatic substituents on the carbon atom C3 of the heterocyclic moiety as shown in Figure 1. 




Previous work



This work

Figure 1. Substitution level at the carbon C3 of the isoxazolidine core.

In order to have further insights on the SAR, we envisioned to pursue the investigation on the nucleoside analogues obtained from a "clean" isoxazolidine ring where carbon C3 is just a methylene; the absence of substituents at this point on the heterocyclic ring could offer more information on how to increase or modify the apoptotic activity of these $\mathrm{N}, \mathrm{O}$-nucleosides. For this reason we chose compound 13A to be derivatized through acetylation and subsequently functionalized with some heterobases belonging to the purine and pyrimidine family to prepare a small library of nucleoside analogues.

Compound 13A was acetylated according to the established procedure ${ }^{13-15}$ affording the derivative 14A in $80 \%$ yield. The fully characterized product was then submitted to heterobase insertion reaction by adapting the Vorbrüggen protocol (Table 3). The reaction were conducted according to the method already used in previous works ${ }^{3,10-12}$ and compounds 15 a-d were obtained from fair to good yields.

The structures of the nucleoside analogues 15a-d rely upon their analytical and spectroscopic data. Typically, in the ${ }^{1} \mathrm{H}$ NMR spectra the presence of the hemiacetal proton at the $\mathrm{C} 5$ of the isoxazolidine moiety is given by a signal in the range $\delta 6.29-6.90 \mathrm{ppm}$; the chemical shift of these protons is slightly changed with respect to that of compound $14 \mathrm{~A}$ found at $\delta 6.41 \mathrm{ppm}$ because of heterobase substitutions.

Table 3. Acetylation and heterobase derivatization reactions of the $\mathrm{N}$-benzoyl-5-hydroxy-isoxazolidine 13A

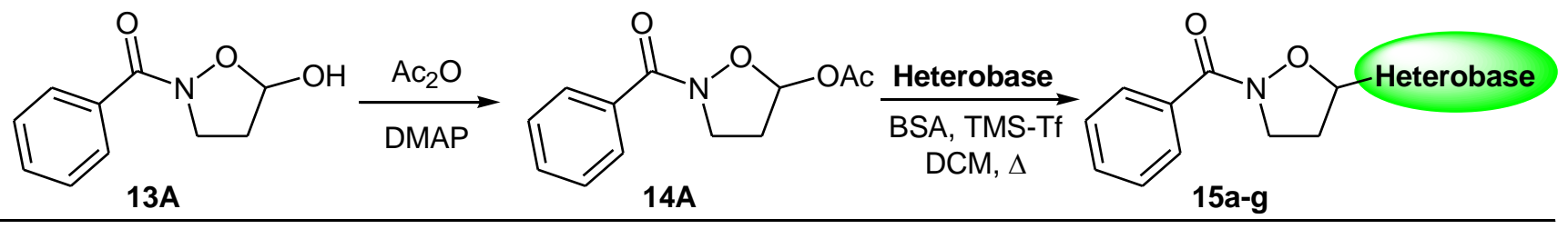<smiles>CC(C)(S)[C@@H]1CN2C[C@H](n3cnc4c(Cl)ncnc43)C1(C(=O)c1ccccc1)O2</smiles>

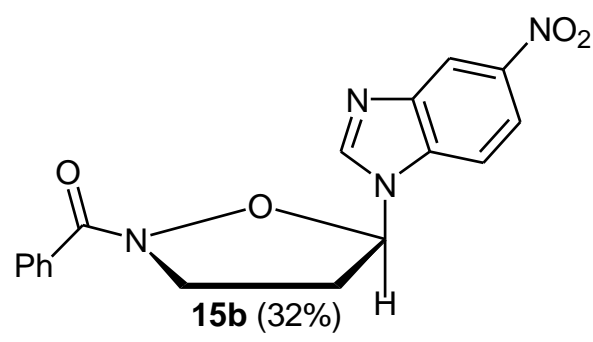<smiles></smiles>

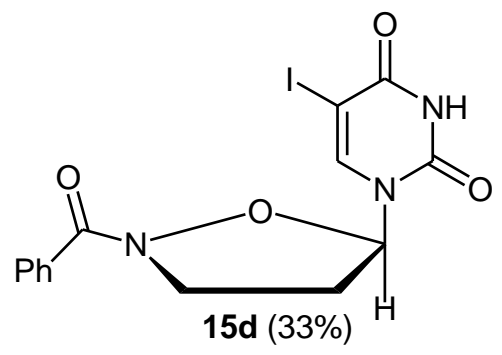


The presence of the heterobases is given in the ${ }^{1} \mathrm{H}$ NMR spectra by the presence of the typical singlets of the 6-chloro-purine ring at $\delta 8.97$ and 8.63 ppm for compound 15a; at $\delta 8.77$ ppm a singlet confirms the nitrobenzoimidazole presence in the structure of 15b. Finally, the halogenated-uracil derivatives $\mathbf{1 5 c , d}$ are characterized by ${ }^{1} \mathrm{H}$ NMR spectra showing deshielded $\mathrm{CH}=\mathrm{C}$ protons at $\delta 7.96$ and $7.92 \mathrm{ppm}$, respectively. Samples of the synthesized compounds 15a-d are currently used for the biological evaluation to assess their pro-apoptotic, metabolic and cytotoxic activities.

\section{Conclusions}

In conclusion, we have demonstrated as the 5-hydroxy-isoxazolidine core can be easily prepared from hydroxamic acids and suitable $\alpha, \beta$-unsaturated aldehydes in good yields from solid state synthesis promoted by DEAE-C as an alternative protocol with respect to the ene approach from nitrosocarbonyl intermediates and allylic alcohols. The SAR investigation we are conducting on the apoptotic activity of isoxazolidine nucleosides takes great advantage from the synthetic methodology hereby presented because it allows for the introduction of novel functional groups on the aromatic ring of the hydroxamic acid moiety that are normally detrimental for the stability of nitrosocarbonyl intermediated (e.g. the OH group) as well as the deletion of any substituent at the position 3 (see Figure 1) of the isoxazolidine core or alternatively the introduction of a substituent in the position 4 of the same heterocyclic ring. These elements, not only enlarge the synthetic potential towards the isoxazolidine target, but also represent a valuable direct demonstration of the validity of the methodology where DEAE-C goes beyond the classical role of solid support for chromatographic purification of biomolecules and assumes the prestigious role of catalyst for organic reactions. We expect that this role could find other interesting applications in organic synthesis due to the intrinsic characteristics of the material. $^{7}$ The synthesized products were efficiently derivatized with representative heterobases for the preparation of nucleoside analogues suitable for biological evaluation.

\section{Experimental Section}

General. All melting points $(\mathrm{mp})$ are uncorrected. Elemental analyses were done on a elemental analyzer available at the Department. ${ }^{1} \mathrm{H}$ and ${ }^{13} \mathrm{C}$ NMR spectra were recorded on a $300 \mathrm{MHz}$ spectrometer (solvents specified). Chemical shifts are expressed in ppm from internal tetramethylsilane $(\delta)$ and coupling constants (J) are in Hertz (Hz): b, broad; s, singlet; bs, broad singlet; $d$, doublet; $t$, triplet; q, quartet; m, multiplet. IR spectra (nujol mulls) were recorded on a spectrophotometer available at the Department and absorbtions ( $v$ are in $\mathrm{cm}^{-1}$. Column chromatography and tlc: silica gel $\mathrm{H} 60$ and $\mathrm{GF}_{254}$, respectively; eluants: cyclohexane/ethyl acetate 9:1 to pure ethyl acetate; MPLC Biotage Flash Master Personal; eluants: cyclohexane/ethyl acetate 9:1 to pure ethyl acetate. $R_{f}$ calculated for cyclohexane/ethyl acetate 1:1 mixtures.

Starting and reference materials. Hydroxamic acids 11a-d and the aldehydes 12a-d were purchased from Sigma-Aldrich. DEAE-C was also purchased from Sigma-Aldrich 16505, CAS n 9013-34-7; DiethylaminoethylSephacel ${ }^{\circledR}$. Other reagents and solvents were purchased from chemical suppliers and used without any further purification.

General procedure for the synthesis of 5-hydroxy-isoxazolidines 13 . DEAE-C ( $5 \mathrm{~g})$ is placed in a mortar and 5 mmol of the hydroxamic acid and aldehyde of choice is added. The mixture is mixed with a pestle carefully for 
2 hours (even not continually). The mixed solid material is left at room temperature for additional 2 hours before dissolving in DCM $(100 \mathrm{~mL})$ and water $(100 \mathrm{~mL})$; extraction allowed for the collection of the organic products that were purified by column chromatography.

Compounds $\mathbf{1 3 A}, \mathbf{G}$ are obtained as single products; compounds $\mathbf{1 3 B}, \mathbf{D}, \mathbf{E}, \mathbf{F}, \mathbf{H}$ were obtained as mixtures of diastereoisomers: hereby the characterization is given just for the major diasteroisomer. Compound $\mathbf{1 3 C}$ is a known compound and its characterization is reported in literature. ${ }^{16}$ Melting point values refer to the beginning of the solid melting followed by decomposition.

N-Benzoyl-5-hydroxyisoxazolidine (13A). Yield: 0.64 g $(66 \%)$; dark yellowish crystals from ethanol/diisopropylether, $\mathrm{mp} 53-55^{\circ} \mathrm{C} . \mathrm{R}_{f} 0.20$. IR $\mathrm{v}_{\mathrm{OH}} 3308, \mathrm{v}_{\mathrm{C}=0} 1624 \mathrm{~cm}^{-1} .{ }^{1} \mathrm{H}$ NMR $\left(\mathrm{CDCl}_{3}, 300 \mathrm{MHz}\right): \delta=7.72$ (m, 2H, Ph), 7.38 (m, 3H, Ph), 5.69 (bs, 1H, O-CH-OH), $4.06(\mathrm{~m}, 1 \mathrm{H}, \mathrm{CH}-\mathrm{N}), 3.69(\mathrm{~m}, 1 \mathrm{H}, \mathrm{CH}-\mathrm{N}), 2.28(\mathrm{~m}, 2 \mathrm{H}$, $\left.\mathrm{CH}_{2}\right) .{ }^{13} \mathrm{C} \mathrm{NMR}\left(\mathrm{CDCl}_{3}, 75 \mathrm{MHz}\right): \delta=169.6(\mathrm{C}=\mathrm{O}), 133.6,131.0,129.0,128.6,127.9$ (Arom.), $97.6(\mathrm{O}-\mathrm{CH}-\mathrm{OH})$, $44.5\left(\mathrm{CH}_{2}-\mathrm{N}\right), 34.5\left(\mathrm{CH}_{2}\right)$. Anal. Calcd for $\mathrm{C}_{10} \mathrm{H}_{11} \mathrm{NO}_{3}$ (193.20): C, 62.17; $\mathrm{H}, 5.74 ; \mathrm{N}, 7.25$. Found: $\mathrm{C}, 62.18 ; \mathrm{H}, 5.73$; $\mathrm{N}, 7.26$.

N-Benzoyl-3-methyl-5-hydroxyisoxazolidine (13B). Yield: 0.65 g $(63 \%)$; white crystals from ethanol/diisopropylether, $\mathrm{mp} 104-105^{\circ} \mathrm{C} . \mathrm{R}_{f} 0.22$. IR $v_{\mathrm{OH}} 3310, v_{\mathrm{C}=0} 1626 \mathrm{~cm}^{-1} .{ }^{1} \mathrm{H} \mathrm{NMR}\left(\mathrm{CDCl}_{3}, 300 \mathrm{MHz}\right): \delta=$ $7.73(\mathrm{~m}, 2 \mathrm{H}, \mathrm{Ph}), 7.44(\mathrm{~m}, 3 \mathrm{H}, \mathrm{Ph}), 5.61(\mathrm{~d}, 1 \mathrm{H}, \mathrm{J} 5 \mathrm{~Hz}, \mathrm{O}-\mathrm{CH}-\mathrm{OH}), 4.72\left(\mathrm{~m}, 1 \mathrm{H}, \mathrm{CH}_{3}-\mathrm{CH}-\mathrm{N}\right), 3.71(\mathrm{~b}, 1 \mathrm{H}, \mathrm{OH}), 2.45$ and $2.05\left(\mathrm{~m}, 1 \mathrm{H}+1 \mathrm{H}, \mathrm{CH}_{2}\right), 1.38\left(\mathrm{~d}, 3 \mathrm{H}, \mathrm{J} 7 \mathrm{~Hz}, \mathrm{CH}_{3}\right) .{ }^{13} \mathrm{C} \mathrm{NMR}\left(\mathrm{CDCl}_{3}, 75 \mathrm{MHz}\right): \delta=171.3(\mathrm{C}=0), 133.6,130.4$, 128.9, 128.7, 127.4 (Arom.), $98.0(\mathrm{O}-\mathrm{CH}-\mathrm{OH}), 51.5\left(\mathrm{CH}_{3}-\mathrm{CH}-\mathrm{N}\right), 42.5\left(\mathrm{CH}_{2}\right), 20.5\left(\mathrm{CH}_{3}\right)$. Anal. Calcd for $\mathrm{C}_{11} \mathrm{H}_{13} \mathrm{NO}_{3}$ (207.23): C, 63.76; H, 6.32; N, 6.76. Found: C, 63.77; H, 6.33; N, 6.76.

N-Mesitoyl-3-phenyl-5-hydroxyisoxazolidine (13D). Yield: $0.75 \mathrm{~g}$ (48\%); dark yellowish crystals from ethyl acetate/diisopropylether, $\mathrm{mp} 170-173{ }^{\circ} \mathrm{C} . \mathrm{R}_{f} 0.43$. IR $\mathrm{v}_{\mathrm{OH}} 3300, \mathrm{v}_{\mathrm{C}=0} 1634 \mathrm{~cm}^{-1} .{ }^{1} \mathrm{H} \mathrm{NMR}$ (DMSO, $\left.300 \mathrm{MHz}\right): \delta=$ $7.36(\mathrm{~m}, 5 \mathrm{H}, \mathrm{Ph}), 6.85(\mathrm{~m}, 2 \mathrm{H}, \mathrm{Mes}), 5.54(\mathrm{t}, 1 \mathrm{H}, J 5 \mathrm{~Hz}, \mathrm{O}-\mathrm{CH}-\mathrm{OH}), 5.51(\mathrm{~m}, 1 \mathrm{H}, \mathrm{Ph}-\mathrm{CH}-\mathrm{N}), 2.72$ and $2.27(\mathrm{~m}$, $1 \mathrm{H}+1 \mathrm{H}, \mathrm{CH}_{2}$ ), $2.22\left(\mathrm{~s}, 9 \mathrm{H}, \mathrm{CH}_{3}\right) .{ }^{13} \mathrm{C} N M R$ (DMSO, $\left.75 \mathrm{MHz}\right): \delta=169.5(\mathrm{C}=\mathrm{O}), 142.2,137.4,134.3,133.7,133.4$, 128.6, 128.2, 127.6, 127.4, 127.1, 126.2, 125.8, (Arom.), 97.1 (O-CH-OH), 57.9 (Ph-CH-N), $45.0\left(\mathrm{CH}_{2}\right), 20.6$, 19.1, $19.07\left(\mathrm{CH}_{3}\right)$. Anal. Calcd for $\mathrm{C}_{19} \mathrm{H}_{21} \mathrm{NO}_{3}$ (311.38): C, 73.29; $\mathrm{H}, 6.80 ; \mathrm{N}, 4.50$. Found: $\mathrm{C}, 73.27 ; \mathrm{H}, 6.81 ; \mathrm{N}$, 4.48.

N-(2-Hydroxyphenyl)-3-phenyl-5-hydroxyisoxazolidine (13E). Yield: $0.70 \mathrm{~g}$ (49\%); white crystals from ethyl acetate, $\mathrm{mp} 184-186{ }^{\circ} \mathrm{C} . \mathrm{R}_{f}$ 0.19. IR $\mathrm{v}_{\mathrm{OH}} 3310, v_{\mathrm{C}=\mathrm{O}} 1634 \mathrm{~cm}^{-1} .{ }^{1} \mathrm{H}$ NMR (DMSO, $\left.300 \mathrm{MHz}\right): \delta=10.46(\mathrm{~s}, 1 \mathrm{H}, \mathrm{OH})$, 7.58 (bs, 1H, OH), 7.37 (m, 6H, Ph), $7.14(\mathrm{~m}, 1 \mathrm{H}, \mathrm{Ph}), 6.85(\mathrm{~m}, 2 \mathrm{H}, \mathrm{Ph}), 5.67(\mathrm{t}, 1 \mathrm{H}, J 5 \mathrm{~Hz}, \mathrm{O}-\mathrm{CH}-\mathrm{OH}), 5.60(\mathrm{t}, 1 \mathrm{H}$, $\mathrm{J} 8 \mathrm{~Hz}, \mathrm{Ph}-\mathrm{CH}-\mathrm{N}), 2.70$ and $2.27\left(\mathrm{~m}, 1 \mathrm{H}+1 \mathrm{H}, \mathrm{CH}_{2}\right) .{ }^{13} \mathrm{C} \mathrm{NMR}$ (DMSO, $\left.75 \mathrm{MHz}\right): \delta=157.5(\mathrm{C}=0), 142.1,132.3$, 130.3, 128.9, 128.7, 127.5, 126.5, 126.2, 118.7, 116.7, (Arom.), 98.4 (O-CH-OH), 58.4 (Ph-CH-N), $44.7\left(\mathrm{CH}_{2}\right)$.

Anal. Calcd for $\mathrm{C}_{16} \mathrm{H}_{15} \mathrm{NO}_{4}$ (285.30): C, 67.36; H, 5.30; N, 4.91. Found: C, 67.37; H, 5.31; N, 4.88.

$\mathbf{N}$-(2-Hydroxyphenyl)-3-methyl-5-hydroxyisoxazolidine (13F). Yield: $0.79 \mathrm{~g}$ (71\%); dark yellow crystals from ethyl acetate, $\mathrm{mp} 130-132{ }^{\circ} \mathrm{C} . \mathrm{R}_{f} 0.18$. IR $\mathrm{v}_{\mathrm{OH}} 3311, \mathrm{v}_{\mathrm{C}=\mathrm{O}} 1624 \mathrm{~cm}^{-1} .{ }^{1} \mathrm{H} \mathrm{NMR}$ (DMSO, $\left.300 \mathrm{MHz}\right): \delta=10.45(\mathrm{~s}, 1 \mathrm{H}$, $\mathrm{OH}), 7.29(\mathrm{~m}, 2 \mathrm{H}, \mathrm{Ph}), 6.87(\mathrm{~m}, 2 \mathrm{H}, \mathrm{Ph}), 5.81(\mathrm{~m}, 1 \mathrm{H}, \mathrm{O}-\mathrm{CH}-\mathrm{OH}), 4.11(\mathrm{~m}, 1 \mathrm{H}, \mathrm{CH}-\mathrm{Me}), 1.74$ and $2.75(\mathrm{~m}, 1 \mathrm{H}+1 \mathrm{H}$, $\mathrm{CH}_{2}$ ), 1.25 and $1.18\left(\mathrm{~d}, 3 \mathrm{H}, \mathrm{J} 7 \mathrm{~Hz}, \mathrm{CH}_{3}\right) \cdot{ }^{13} \mathrm{C} \mathrm{NMR}$ (DMSO, $\left.75 \mathrm{MHz}\right): \delta=167.5(\mathrm{C}=\mathrm{O}), 120.4,118.5,116.3,116.2$, (Arom.), $97.9(\mathrm{O}-\mathrm{CH}-\mathrm{OH}), 78.2(\mathrm{CH}-\mathrm{Me}), 44.1\left(\mathrm{CH}_{2}\right), 17.8(\mathrm{Me})$. Anal. Calcd for $\mathrm{C}_{11} \mathrm{H}_{13} \mathrm{NO}_{4}(223.23): \mathrm{C}, 59.19 ; \mathrm{H}$, 5.87; N, 6.27. Found: C, 59.17; H, 5.86; N, 6.28.

$\mathbf{N}$-(4-Carboxymethylphenyl)-5-hydroxyisoxazolidine (13G). Yield: $0.83 \mathrm{~g}$ (66 \%); thick oil. $\mathrm{R}_{f} 0.43 . \mathrm{IR} \mathrm{v}_{\mathrm{OH}} 3315$,

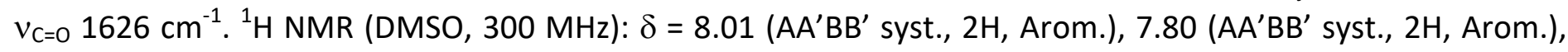
$6.99(\mathrm{~d}, 1 \mathrm{H}, J 5 \mathrm{~Hz}, \mathrm{OH}), 5.56(\mathrm{t}, 1 \mathrm{H}, J 5 \mathrm{~Hz}, \mathrm{O}-\mathrm{CH}-\mathrm{OH}), 4.15$ and $3.56\left(\mathrm{~m}, 1 \mathrm{H}+1 \mathrm{H}, \mathrm{CH}_{2}-\mathrm{N}\right), 3.88(\mathrm{~s}, 3 \mathrm{H}, \mathrm{OMe}), 2.30$ and $2.09\left(\mathrm{~m}, 1 \mathrm{H}+1 \mathrm{H}, \mathrm{CH}_{2}\right) .{ }^{13} \mathrm{C} \mathrm{NMR}$ (DMSO, $\left.75 \mathrm{MHz}\right): \delta=169,2,165.7,(\mathrm{C}=\mathrm{O}), 138.5,131.2,129.0,128.7$ (Arom.), $97.5(\mathrm{O}-\mathrm{CH}-\mathrm{OH}), 52.4\left(\mathrm{CH}_{2}-\mathrm{N}\right), 43.2\left(\mathrm{CH}_{2}\right), 34.1$ (OMe).

Anal. Calcd for $\mathrm{C}_{12} \mathrm{H}_{13} \mathrm{NO}_{5}$ (251.24): C, 57.37; H, 5.22; N, 5.58. Found: C, 57.37; H, 5.21; N, 5.58. 
$\mathbf{N}$-(Benzoyl)-3-methoxy-5-methyl-5-hydroxyisoxazolidine (13H). Yield: $0.33 \mathrm{~g}$ (28 \%); white crystals from ethyl acetate, $\mathrm{mp} 135-136{ }^{\circ} \mathrm{C}$. IR $v_{\mathrm{OH}} 3316, v_{\mathrm{C}=0} 1632 \mathrm{~cm}^{-1} . \mathrm{R}_{f} 0.33 .{ }^{1} \mathrm{H}$ NMR $\left(\mathrm{CDCl}_{3}, 300 \mathrm{MHz}\right): \delta=9.47(\mathrm{bs}, 1 \mathrm{H}, \mathrm{OH})$, $7.74(\mathrm{~m}, 2 \mathrm{H}, \mathrm{Ph}), 7.49(\mathrm{~m}, 3 \mathrm{H}, \mathrm{Ph}), 5.22(\mathrm{t}, 1 \mathrm{H}, \mathrm{J} 5 \mathrm{~Hz}, \mathrm{~N}-\mathrm{CH}-\mathrm{OMe}), 3.47$ (s, 3H, OMe), 2.95 (AB syst., 2H, $\left.\mathrm{CH}_{2}\right)$, $2.18\left(\mathrm{~s}, 3 \mathrm{H}, \mathrm{CH}_{3}\right) .{ }^{13} \mathrm{C} \mathrm{NMR}\left(\mathrm{CDCl}_{3}, 75 \mathrm{MHz}\right): \delta=167.0,(\mathrm{C}=\mathrm{O}), 132.1,128.6,127.1,126.8$ (Arom.), $105.5(\mathrm{~N}-\mathrm{CH}-$ OMe), $56.9\left(\mathrm{CH}_{3}\right), 46.6\left(\mathrm{CH}_{2}\right), 30.7\left(\mathrm{CH}_{3}\right)$. Anal. Calcd for $\mathrm{C}_{12} \mathrm{H}_{15} \mathrm{NO}_{4}$ (237.26): $\mathrm{C}, 60.75 ; \mathrm{H}, 6.37 ; \mathrm{N}, 5.90$. Found: C, $60.77 ; \mathrm{H}, 6.35 ; \mathrm{N}, 5.88$.

Synthesis of the 2-benzoylisoxazolidin-5-yl acetate 14A. To an ice-cooled anhydrous DCM (50 mL) solution of $\mathrm{N}$-Benzoyl-5-hydroxyisoxazolidine (13A) (4.78 mmol.), 1.2 equiv. of $\mathrm{Ac}_{2} \mathrm{O}$ were added under stirringlong with 0.3 equiv. of DMAP and 1.3 equiv. of $\mathrm{Et}_{3} \mathrm{~N}$. The reaction is left under stirring at r.t. for $24 \mathrm{~h}$. After dilution with an equivalent volume of DCM, the organic phase was washed with a saturated solution of $\mathrm{NaHCO}_{3}$ and dried over anhydrous $\mathrm{Na}_{2} \mathrm{SO}_{4}$. The solvent is then evaporated and a solid is obtained.Yield: $0.90 \mathrm{~g}(80 \%) ;$ oil. $\mathrm{R}_{f} 0.50$. IR $v_{\mathrm{C}=0} 1635,1624 \mathrm{~cm}^{-1} .{ }^{1} \mathrm{H} \mathrm{NMR}\left(\mathrm{CDCl}_{3}, 300 \mathrm{MHz}\right): \delta=7.81(\mathrm{~m}, 2 \mathrm{H}, \mathrm{Ph}), 7.47(\mathrm{~m}, 3 \mathrm{H}, \mathrm{Ph}), 6.41(\mathrm{~d}, 1 \mathrm{H}, J 5 \mathrm{~Hz}, \mathrm{O}-$ $\mathrm{CH}-\mathrm{OAc}), 4.47$ and $3.65\left(\mathrm{~m}, 1 \mathrm{H}+1 \mathrm{H}, \mathrm{CH}_{2}-\mathrm{N}\right), 2.55$ and $2.38\left(\mathrm{~m}, 1 \mathrm{H}+1 \mathrm{H}, \mathrm{CH}_{2}\right), 1.75\left(\mathrm{~s}, 3 \mathrm{H}, \mathrm{COCH}_{3}\right) .{ }^{13} \mathrm{C} \mathrm{NMR}$ $\left(\mathrm{CDCl}_{3}, 75 \mathrm{MHz}\right): \delta=174.3,169.2(\mathrm{C}=\mathrm{O}), 132.7,131.4,129.3,127.7$ (Arom.), 95.6 (O-CH-OAc), $43.0\left(\mathrm{CH}_{2}-\mathrm{N}\right.$ ), $33.1\left(\mathrm{COCH}_{3}\right), 20.4\left(\mathrm{CH}_{2}\right)$. Anal. Calcd for $\mathrm{C}_{12} \mathrm{H}_{13} \mathrm{NO}_{4}$ (235.24): C, 61.27; $\mathrm{H}, 5.57 ; \mathrm{N}, 5.95$. Found: $\mathrm{C}, 61.28 ; \mathrm{H}$, $5.53 ; \mathrm{N}, 5.96$.

General procedure for the synthesis of nucleosides $15 \mathrm{a}-\mathrm{d}$ by coupling of isoxazolidine $14 \mathrm{~A}$ and selected heterobases. A solution of 2 equiv. of heterobases (see Table 3 ) and 2 equiv. of bis(trimethylsilyl)acetamide (BSA) in anhydrous DCM (50 mL) is refluxed under nitrogen atmosphere for 15-20 min. until it becomes clear and hence cooled to room temperature. A solution in DCM $(10 \mathrm{~mL})$ of isoxazolidines $14 \mathrm{~A}(0.20 \mathrm{~g}, 0.65 \mathrm{mmol})$ is added dropwise and cooled to $0{ }^{\circ} \mathrm{C}$ and additioned of $0.12 \mathrm{~mL}$ (1 equiv.) of TMSO-Tf. The reaction is refluxed under stirring overnight and finally quenched with a saturated solution of $\mathrm{NaHCO}_{3}$ at $\mathrm{pH}=7$. The mixture is diluted with an equivalent volume of $\mathrm{DCM}$ and washed with water and finally dried over $\mathrm{Na}_{2} \mathrm{SO}_{4}$. After filtration, the solvent is evaporated and, from the residues, nucleosides 15a-d are isolated upon column chromatographic purification.

Compound 15a. Yield: $0.07 \mathrm{~g}$ (33 \%); yellowish crystals from ethanol/diisopropylether, $\mathrm{mp} 151-152{ }^{\circ} \mathrm{C} . \mathrm{R}_{f} 0.44$. IR $v_{\mathrm{C}=0} 1654 \mathrm{~cm}^{-1} .{ }^{1} \mathrm{H}$ NMR (DMSO, $\left.300 \mathrm{MHz}\right): \delta=8.97$ and $8.63(\mathrm{~s}, 1 \mathrm{H}+1 \mathrm{H}, \mathrm{CH}=\mathrm{N}), 7.15(\mathrm{~m}, 2 \mathrm{H}, \mathrm{Ph}), 7.06(\mathrm{~m}$, $3 \mathrm{H}, \mathrm{Ph}), 6.90(\mathrm{~d}, 1 \mathrm{H}, J 3 \mathrm{~Hz}, \mathrm{O}-\mathrm{CH}-\mathrm{N}), 4.67$ and $3.72\left(\mathrm{~m}, 1 \mathrm{H}+1 \mathrm{H}, \mathrm{CH}_{2}-\mathrm{N}\right), 3.25$ and $3.02\left(\mathrm{~m}, 1 \mathrm{H}+1 \mathrm{H}, \mathrm{CH}_{2}\right) .{ }^{13} \mathrm{C}$ NMR (DMSO, $75 \mathrm{MHz}): \delta=162.2(\mathrm{C}=\mathrm{O}), 151.9,147.8(\mathrm{CH}=\mathrm{N}), 142.6(\mathrm{C}=\mathrm{N}), 131.1,130.9,127.6,127.0$ (Arom.), $122.1(\mathrm{C}), 85.4(\mathrm{O}-\mathrm{CH}-\mathrm{N}), 43.8\left(\mathrm{CH}_{2}-\mathrm{N}\right), 30.4\left(\mathrm{CH}_{2}\right)$. Anal. Calcd for $\mathrm{C}_{15} \mathrm{H}_{12} \mathrm{ClN}_{5} \mathrm{O}_{2}(329.74): \mathrm{C}, 54.64 ; \mathrm{H}, 3.67 ; \mathrm{N}$, 21.24. Found: $\mathrm{C}, 54.65 ; \mathrm{H}, 3.66 ; \mathrm{N}, 21.26$.

Compound 15b. Yield: $0.07 \mathrm{~g}$ (32\%); yellow crystals from ethanol/diisopropylether, $\mathrm{mp} 176-179{ }^{\circ} \mathrm{C} . \mathrm{R}_{f} 0.51$. IR $v_{\mathrm{C}=0} 1654 \mathrm{~cm}^{-1} .{ }^{1} \mathrm{H}$ NMR (DMSO, $\left.300 \mathrm{MHz}\right): \delta=8.77(\mathrm{~s}, 1 \mathrm{H}, \mathrm{CH}=\mathrm{N}), 7.98(\mathrm{~m}, 2 \mathrm{H}$, Arom.), 7.73 (d, 1H, Arom.), $7.06(\mathrm{~m}, 2 \mathrm{H}, \mathrm{Ph}), 6.96(\mathrm{~m}, 3 \mathrm{H}, \mathrm{Ph}), 6.89(\mathrm{~d}, 1 \mathrm{H}, \mathrm{J} 3 \mathrm{~Hz}, \mathrm{O}-\mathrm{CH}-\mathrm{N}), 4.57$ and $3.75\left(\mathrm{~m}, 1 \mathrm{H}+1 \mathrm{H}, \mathrm{CH}_{2}-\mathrm{N}\right), 3.27$ and 2.97 $\left(\mathrm{m}, 1 \mathrm{H}+1 \mathrm{H}, \mathrm{CH}_{2}\right) \cdot{ }^{13} \mathrm{C}$ NMR (DMSO, $\left.75 \mathrm{MHz}\right): \delta=162.2(\mathrm{C}=\mathrm{O}), 146.6(\mathrm{CH}=\mathrm{N}), 137.8(\mathrm{C}=\mathrm{N}), 131.9,130.7,130.4$, 127.7, 127.5, 127.3, 127.2, 119.6 (Arom.), 124.9 (C), $84.3(\mathrm{O}-\mathrm{CH}-\mathrm{N}), 43.4\left(\mathrm{CH}_{2}-\mathrm{N}\right), 30.8\left(\mathrm{CH}_{2}\right)$. Anal. Calcd for $\mathrm{C}_{17} \mathrm{H}_{14} \mathrm{~N}_{4} \mathrm{O}_{4}$ (338.32): C, 60.35; $\mathrm{H}, 4.17 ; \mathrm{N}, 16.56$. Found: $\mathrm{C}, 60.35 ; \mathrm{H}, 4.16 ; \mathrm{N}, 16.57$.

Compound 15c. Yield: $0.05 \mathrm{~g}(22 \%)$; white crystals from ethanol/diisopropylether, $\mathrm{mp} 141-143^{\circ} \mathrm{C} . \mathrm{R}_{f} 0.38$. IR $v_{\mathrm{C}=0} 1654 \mathrm{~cm}^{-1} .{ }^{1} \mathrm{H}$ NMR (DMSO, $\left.300 \mathrm{MHz}\right): \delta=11.80$ (bs, 1H, NH), $7.96(\mathrm{~s}, 1 \mathrm{H}, \mathrm{CH}=\mathrm{C}), 7.57(\mathrm{~m}, 2 \mathrm{H}, \mathrm{Ph}), 7.43$ $(\mathrm{m}, 3 \mathrm{H}, \mathrm{Ph}), 6.31(\mathrm{~m}, 1 \mathrm{H}, \mathrm{O}-\mathrm{CH}-\mathrm{N}), 4.29$ and $3.81\left(\mathrm{~m}, 1 \mathrm{H}+1 \mathrm{H}, \mathrm{CH}_{2}-\mathrm{N}\right), 2.73\left(\mathrm{~m}, 2 \mathrm{H}, \mathrm{CH}_{2}\right) .{ }^{13} \mathrm{C}$ NMR (DMSO, 75 $\mathrm{MHz}): \delta=170.3,158.7,155.8(\mathrm{C}=\mathrm{O}), 149.6(\mathrm{CH}=\mathrm{C}), 137.9,132.8,131.5,130.7,128.2,127.8,127.4$ (Arom.), $107.7(\mathrm{C}), 97.4(\mathrm{O}-\mathrm{CH}-\mathrm{N}), 86.0(\mathrm{C}-\mathrm{Cl}), 45.3\left(\mathrm{CH}_{2}-\mathrm{N}\right), 30.3\left(\mathrm{CH}_{2}\right)$. Anal. Calcd for $\mathrm{C}_{14} \mathrm{H}_{12} \mathrm{ClN}_{3} \mathrm{O}_{4}(321.72): \mathrm{C}, 52.27$; $H, 3.76 ; \mathrm{N}, 13.06$. Found: $\mathrm{C}, 52.25 ; \mathrm{H}, 3.76 ; \mathrm{N}, 12.06$.

Compound $15 \mathrm{~d}$. Yield: $0.09 \mathrm{~g}$ (33\%); straw crystals from ethanol/diisopropylether, $\mathrm{mp} 198{ }^{\circ} \mathrm{C}$ (dec.). $\mathrm{R}_{f} 0.37$. 
IR $v_{\mathrm{C}=0} 1654 \mathrm{~cm}^{-1} .{ }^{1} \mathrm{H}$ NMR (DMSO, $300 \mathrm{MHz}$ ): $\delta=11.68$ (bs, 1H, NH), $7.92(\mathrm{~s}, 1 \mathrm{H}, \mathrm{CH}=\mathrm{C}), 7.58(\mathrm{~m}, 2 \mathrm{H}, \mathrm{Ph}), 7.44$ $(\mathrm{m}, 3 \mathrm{H}, \mathrm{Ph}), 6.29(\mathrm{t}, 1 \mathrm{H}, \mathrm{J} 5 \mathrm{~Hz}, \mathrm{O}-\mathrm{CH}-\mathrm{N}), 4.26$ and $3.77\left(\mathrm{~m}, 1 \mathrm{H}+1 \mathrm{H}, \mathrm{CH}_{2}-\mathrm{N}\right), 2.73\left(\mathrm{~m}, 2 \mathrm{H}, \mathrm{CH}_{2}\right) .{ }^{13} \mathrm{C} N M R$ (DMSO, $75 \mathrm{MHz}$ ): $\delta=170.3,160.3,150.1(\mathrm{C}=\mathrm{O}), 144.7$ ( $\mathrm{CH}=\mathrm{C}), 132.9,131.5,129.4,128.6,128.4,127.9,127.7$ (Arom.), $127.3(\mathrm{C}), 97.4(\mathrm{O}-\mathrm{CH}-\mathrm{N}), 86.0(\mathrm{C}-\mathrm{I}), 45.3\left(\mathrm{CH}_{2}-\mathrm{N}\right), 30.4\left(\mathrm{CH}_{2}\right)$. Anal. Calcd for $\mathrm{C}_{14} \mathrm{H}_{12} \mathrm{IN}_{3} \mathrm{O}_{4}(413.17): \mathrm{C}, 40.70 ; \mathrm{H}$, $2.93 ; \mathrm{N}, 10.17$. Found: $\mathrm{C}, 40.71 ; \mathrm{H}, 2.94 ; \mathrm{N}, 10.16$.

\section{Acknowledgements}

Financial support by the University of Pavia is gratefully acknowledged.

Thanks are due to "VIPCAT - Value Added Innovative Protocols for Catalytic Transformations" project (CUP: E46D17000110009) for valuable financial support.

\section{Supplementary Material}

${ }^{1} \mathrm{H}$ and ${ }^{13} \mathrm{C}$ NMR spectra of reported structures are given in the supplementary material file associated to this manuscript.

\section{References}

1. Quadrelli, P. in Modern Applications of Cycloaddition Chemistry Quadrelli, P. Eds.; Elsevier: Amsterdam, 2019; pp 85-152.

https://doi.org/10.1016/B978-0-12-815273-7.00002-2

2. Dou, Q.-Y.; Tu, Y.-Q.; Zhang, Y.; Tian, J.-M.; Zhang, F.-M.; Wang, S.-H. Adv. Synth. Catal. 2016, $358,874$. https://doi.org/10.1002/adsc.201501025

3. Memeo, M. G.; Valletta, E.; Macchi, B.; Porta, A. ; Bovio, B.; Moiola, M.; Quadrelli, P. ACS Omega 2018, 3, 7621-7629. https://doi.org/10.1021/acsomega.8b00970

4. Sharma, P.; Liu, R.-S. Org. Lett. 2016, 18, 412. https://doi.org/10.1021/acs.orglett.5b03447

5. Presenti, P.; Moiola, M.; Quadrelli, P. Chem. Select 2020, submitted.

6. Memeo, M. G.; Quadrelli, P. Chem. Rev. 2017, 117, 2108. https://doi.org/10.1021/acs.chemrev.6b00684

7. Aljaf, K. K.; Amin, A. A.; Faiq, H. S. H.; Quadrelli, P. Monat. Chem. 2020, submitted.

8. Motorina, I. A.; Sviridova, L. A.; Golubeva, G. A.; Bundel, Yu. G. Tetrahedron Lett. 1989, 30, 117. https://doi.org/10.1016/S0040-4039(01)80339-7

9. Vorbrüggen, H.; Ruh-Pohlenz, C. Handbook of Nucleoside Synthesis, Wiley: New York, 2001.

10. Quadrelli, P.; Mella, M.; Carosso, S.; Bovio, B. J. Org. Chem. 2013, 78, 516-526. https://doi.org/10.1021/jo302346a

11. Baidya, M.; Yamamoto, H. Synthesis 2013, 45, 1931-1938. https://doi.org/10.1055/s-0033-1339175

12. Carosso, S.; Memeo, M. G.; Bovio, B.; Valletta, E.; Macchi, B.; Quadrelli, P. Synthesis 2017, 49, $1972-1982$. 
https://doi.org/10.1055/s-0036-1588695

13. Xiang, Y.; Gong, Y.; Zhao, K. Tetrahedron Lett. 1996, 37, 4877-4880.

https://doi.org/10.1016/0040-4039(96)00999-9

14. Zhang, X.; Qing, F.-L.; Yu, Y. J. Org. Chem. 2000, 65, 7075-7082.

https://doi.org/10.1021/jo005520r

15. Zhang, X.; Xia, H.; Dong, X.; Jin, J.; Meng, W.-D.; Qing, F.- L. J. Org. Chem. 2003, 68, 9026-9033. https://doi.org/10.1021/j0034512i

16. Zaborsky, O.; Stadaniova, R.; Dohanosova, J.; Moncol, J.; Fischer, R. Synthesis 2017, 49, 4942-4954. https://doi.org/10.1055/s-0036-1590924 